\title{
Revisiting the External Dimension of the Autonomy of EU Law: Is There Anything New Under the Sun?*
}

\author{
BY TAMÁS MolnÁR**
}

\begin{abstract}
The concept of the autonomy of EU law has received, since its inception in the 1960s, remarkably little academic attention when compared to other basic EU law premises such as "primacy" or "direct effect", particularly from the theoretical angle. However, "autonomy" is undisputedly a fundamental and structural principle of the EU legal order. Given the reflexive nature of the term "autonomy", to be distinct from something and to be able to function separately, it presupposes one or more points of reference. If these are assumed in the form of legal orders, the autonomy of EU law can be basically conceived in two ways: vis-à-vis international law or the legal systems of Member States. The concept of autonomy is traditionally perceived with regard to international law (external dimension of autonomy) as leading judgments of the Court of Justice of the EU and many of its Opinions have further developed this doctrine. This short piece attempts to clarify the meaning of the external dimension of autonomy of EU law and discuss some of the associated challenges. In this context, the paper portrays the various legal techniques and substantive requirements for preserving the external autonomy of the EU legal order from international law.

Keywords: relationship between EU law and international law, autonomy of EU law, Court of Justice of the European Union, constitutionalisation of EU law, Opinion 2/13
\end{abstract}

\section{SETTING THE SCENE: THE CONCEPT OF "AUTONOMY OF EU LAW" IN THE UNION'S LEGAL ARCHITECTURE}

The concept of 'autonomy of European Union (EU) law' has received, since its judge-made inception in the 1960s, remarkably little academic attention particularly from the theoretical or conceptual angle when compared to other basic EU law premises, like supremacy or direct effect. ${ }^{1}$ The autonomous nature of this distinct body of law has been taken for granted by many EU law scholars and other related topics have been in the spotlight which is evident by the ever-expanding literature dealing with the legal effects of international law within the EU legal order $^{2}$ as well as the external relations law of the EU. ${ }^{3}$ These legal issues cannot be properly understood without an in-depth knowledge about the wider context of these interactions and how autonomous the EU legal order is from the international legal system.

* This article was prepared with the support of the János Bolyai Research Scolarship of the Hungarian Academy of Scienses.

** Adjunct professor, Corvinus University of Budapest, Institute of International Studies. E-mail: tamas.molnar@uni-corvinus.hu

1 Since the new millennium, the specifically "autonomy-centred" EU law scholarship has been represented by e.g. Barents (2004); Szurek (2007) 57-92; de Witte (2010) 141-155; Tsagourias (2011) 339-351; Czuczai (2012) 452-472; Dubout (2012) 17-51; Wessel, Blockmans (2013); Pernice (2013) $55-80$.

2 See, for instance, Kaddous (2008); Kuijper (2008); Cannizzaro (2011); Ziegler (2011) 268327; Benlolo-Carabot, Candas, Cujo (2012); Mendez (2013); Wessel (2013) or in the recent Hungarian legal literature Szabó (2012) 191-211; Mohay (2014) 269-281.

3 Almost all EU law textbooks devote a chapter to this issue, and there are many specific commentaries, monographs or handbooks published on this topic, too (e.g. Louis et al (2005); Cremona, de Witte (2008); Eckhout (2011); Dashwood, Maresceau (2011); van Voren, Wessel (2014). 
This doctrine of cardinal significance has existed since the 1960s, with some peak periods of increased interest in the 1990s and in the mid-2000s. The Opinion 2/13 of the Court of Justice of the European Union (CJEU), ${ }^{4}$ delivered on 18 December 2014, reignited interest in the content and meaning of the autonomy of EU law, even though this wellsettled doctrine, elaborated by the CJEU case law, had been around for a long time. After this Opinion, a new wave of scholarly writings has focused on the ramifications of the autonomy of EU law, contributing to the renaissance of the concept, but principally in connection with the Union's accession to the European Convention on Human Rights (ECHR). These articles have commented and analysed the Court's autonomy-related arguments in the context of this Opinion. ${ }^{5}$ Autonomy, despite being in the background for the majority of its more than fifty years' existence, is an undisputed fundamental and structural principle of the EU legal order and is believed to be part of "the very foundations of the Union legal order". 6

In essence, the concept of autonomy oversteps the traditional divide between international law and domestic law by giving birth to a new category of law, a "new legal order, which is meant to be the EU legal system. In order for a normative system be autonomous, it must not be subject to external legal norms. ${ }^{7}$ In the EU context, this has been stipulated by the CJEU 'the very nature of EU law [...] requires that relations between Member States be governed by EU law to the exclusion [...] of any other law. ${ }^{8}$ Given the reflexive nature of autonomy, to be distinct from something and to be able to function separately (self-standing nature), it presupposes one or more points of reference. If these points of reference are assumed in the form of legal orders, the autonomy of Union law can be basically conceived as vis-à-vis international law, which represents the "external aspect of autonomy" or in relation to the domestic legal systems of the Member States, the "internal aspect of autonomy". This kind of conceptualisation clearly appears in Opinion 2/13, where the autonomy, enjoyed by EU law, was expressly conceived "in relation to the laws of the Member States and in relation to international law." Advocate General Kokott also made this distinction in her View delivered on 13 June 2014, when she stated that "autonomy is not only characteristic of the relationship between EU law and the laws of the Member States, but must be respected also vis-à-vis third countries and international

${ }^{4}$ Opinion 2/13, Draft agreement providing for the accession of the European Union to the European Convention for the Protection of Human Rights and Fundamental Freedoms, Opinion of the Court (Full Court) of 18 December 2014, ECLI:EU:C:2014:2454.

${ }^{5}$ A good illustration for this is Volume 16 of the German Law Journal, which has devoted a special section to comment and discuss the ramifications of Opinion 2/13. Consider also e.g. 'Editorial Comments' (2015), 1-16; Eckhout (2015); Odermatt (2015) and in the Hungarian EU law literature, Mohay (2015) 29-36; Láncos (2015). For the blog entries, see for instance $<$ http://verfassungsblog. de/oops-das-gutachten-des-eugh-zum-emrk-beitritt-der-eu/\#.VNccTmBybIU; http://eulawanalysis. blogspot.hu/2015/02/opinion-213-on-eu-accession-to-echr.html; http://europeanlawblog.eu/?p=2731; https://ukconstitutionallaw.org/2014/12/24/sionaidh-douglas-scott-opinion-213-on-eu-accessionto-the-echr-a-christmas-bombshell-from-the-european-court-of-justice/; http://verfassungsblog.de/aconstitutional-defense-of-cjeu-opinion-213-on-eu-accession-to-the-echr-and-the-way-forward/> or in Hungarian, <http://jog.tk.mta.hu/blog/2015/02/kulon-marad-ami-osszetartozik> accessed 1 April 2016.

6 Van Rossem (2013) 18; Wessel, Blockmans (2013).

7 Troper (2002) 66.

8 ECLI:EU:C:2014:2454, para. 40.

9 ECLI:EU:C:2014:2454, para. 170. 
organisations". ${ }^{10}$ This judicial pronouncement, making the explicit distinction between the two dimensions of autonomy, has echoed what had already been identified by academia. ${ }^{11}$ Nevertheless, legal concepts, particularly highly abstract ones, often have 'open texture' (using Hart's terms), which is particularly true for the doctrine of the autonomy of EU law. Odermatt observed that "the problem is that 'autonomy' is a notoriously vague and illdefined concept and can be applied in a narrow or open fashion."12 Therefore this cornerstone principle is still a controversially discussed issue in EU law and in any event, the concept of autonomy can exhibit different features which will depend on the circumstances of the case. ${ }^{13}$

This short piece attempts to clarify the meaning of the external dimension of autonomy of EU law and discuss some of the associated challenges. The theoretical prerequisites of any 'legal order', including its autonomous regime of validity and its mechanism guaranteeing the unity of interpretation will also be briefly studied. The hype that Opinion $2 / 13$ created around this aspect of EU law autonomy, is worth a more general and holistic approach and thus this article will not be limited within the perimeters of this landmark Opinion. Due to the limited length of this article, Opinion 2/13 will only be touch upon, to a necessary extent, with a view to demonstrating the evolution of the external dimension of the autonomy of EU law against the backdrop of the CJEU's previous jurisprudence. Subsequently, the paper will portray the various legal techniques and substantive requirements for preserving the external autonomy of the EU legal order from international law. The article finishes with some conclusions and an outlook for the future.

\section{THE JURISPRUDENTIAL DEVELOPMENT OF THE EXTERNAL ASPECT OF AUTONOMY}

The concept of autonomy is traditionally perceived in the context of international law shown in the famous judgments of the CJEU in Van Gend en $\operatorname{Loos}^{14}$ and Costa v. E.N.E.L. ${ }^{15}$. Other less-known cases in the $1960 \mathrm{~s}^{16}$ have also elaborated this doctrine in this respect. The positioning of EU law in relation to international law as an initial step in this process is not surprising. The European regional economic and now political integration organization, whether it is the European (Economic) Communities or European Union, has always been and is still based on international treaties. As a result, the very existence and the general framework, including its modification regime, of this inter-governmental organization has been clearly rooted in international law. ${ }^{17}$ The CJEU, famous for its judicial activism, had

10 ECLI:EU:C:2014:2475, para. 159.

11 See e.g. Gautron (2000) 22; de Witte (2010) 142; Tsagourias (2011) 339-40; Pernice (2013)

57; Wessel, Blockmans (2013) 1., or in the Hungarian legal scholarship Berke (2001) 43.

12 Odermatt (2015) 12.

13 Van Rossem (2013) 18.

14 Case 26-62, NV Algemene Transporten Expeditie Onderneming van Gend \& Loos $v$ Netherlands Inland Revenue Administration, Judgment of the Court of 5 February 1963, ECLI:EU:C:1963:1.

15 Case 6-64, Flaminio Costa v E.N.E.L., Judgment of the Court of 15 July 1964, ECLI:EU:C:1964:66.

16 For instance, Joined Cases 90-63 and 91-63, Commission of the European Economic Community $v$ Grand Duchy of Luxembourg and Kingdom of Belgium, Judgment of the Court of 13 November 1964, ECLI:EU:C:1964:80.

17 Similarly, see e.g. de Witte (2010) 141-155; Ziegler (2011) 283-285. 
first pronounced in the Van Gend en Loos judgement that the "Community constitutes a new legal order of international law for the benefit of which Member States have limited their sovereign rights"18 (emphasis added - T.M.), which was later simply referred to as a "new legal order"19 and the mention of international law as its broader normative system of operation disappeared. These magic words were used slightly differently in Costa v E.N.E.L. when the Luxembourg Court added: "by contrast with ordinary international treaties, the EEC Treaty has created its own legal system" (emphasis added - T.M). ${ }^{20}$ It also pinpointed that EU law arose out of an "independent source of law", which is not a fully accurate translation of the expression in the French original ("issu d'une source autonome"). ${ }^{21}$

The Van Gend en Loos and Costa v. E.N.E.L. rulings can be convincingly interpreted as relating to both the external and internal aspects of autonomy. However, there is a logical sequence between the two dimensions as they appear in the above decisions. The judges in Luxembourg had to emancipate first EU law from international law and only after preparing the ground in such a way could CJEU effectively argue that Member States are obliged to accept, within their own legal systems, the autonomous nature and operation of this body of law emanating from the founding Treaties, by means of direct effect, supremacy, preemption etc. Wessel, likewise, argued that "[t]o make certain key principles of EU law (including 'primacy' and 'direct effect') work, the EU needs to stress its autonomous relation vis-à-vis international law". ${ }^{22}$ If EU law is construed by the Court as something completely different and independent from international law and represents a wholly new category of law then Member States cannot apply their ordinary legal techniques and arguments, developed for the domestic reception of norms originating from international law, when it comes to enforcing EU law in the national legal systems, including the subsequently produced legal effects. Consequently, these two hallmark judgments will be referred to throughout this section as predominantly (but not exclusively) articulating the external dimension of the autonomy of EU law.

18 ECLI:EU:C:1963:1, Part II.B., para. 4. In the original, French version of the text (at that time, the United Kingdom was not amongst the members of the European Economic Community (EEC), so English was not an official language of the EEC) it reads as follows: "un nouvel ordre juridique de droit international au profit duquel les Etats membres ont limité leur pouvoirs souverains".

19 Joined Cases 90-63 and 91-63, Commission of the European Economic Community $v$ Grand Duchy of Luxembourg and Kingdom of Belgium, Judgment of the Court of 13 November 1964, ECLI:EU:C:1964:80, p. 1232 ("the [EEC] Treaty [...] establishes a new legal order" or in the French original "un ordre juridique nouveau"). Not only was the expression of "international law" omitted by the Court, but even the order of words has been changed compared to the Van Gend en Loos formula; then this shorter version was later echoed many times in subsequent jurisprudence, e.g. in Opinion 1/91, Draft Agreement relating to the Creation of the European Economic Area, Opinion of the Court of 14 December 1991, ECLI:EU:C:1991:490. In Costa v E.N.E.L., a slightly different formulation was used in the original French version to refer to this sui generis legal order, namely "ordre juridique propre", which was translated in English as "its own legal system" when English became an official language of the EEC.

${ }^{20}$ ECLI:EU:C:1964:66, para. 12. The original French version of the judgment applies the term "un ordre juridique propre". For subsequent jurisprudence, see also Joined Cases 142/80 and 143/80, Amministrazione delle Finanze dello Stato v Essevi SpA and Carlo Salengo, Judgment of the Court of 27 May 1981, ECLI:EU:C:1981:121, para. 8.

21 This "lost in translation" phenomenon is also noticed by de Witte (2010) 142. Other commentators do not consider it problematic; see Pescatore (2010) 5; Pernice (2013) 56.

22 Wessel (2013) 22. 
The ground-breaking judgments in the 1960s, traditionally connected with the genesis of the doctrine of autonomy, had not expressly used this phrasing and the term "autonomy of the Community legal order" was initially and explicitly applied by the Court in its Opinion $1 / 91^{23}$ and subsequently echoed in other Opinions. ${ }^{24}$ Opinion 1/00 should be specifically mentioned as the CJEU finally turned the concept of autonomy "into a more clearly defined external relations legal principle". ${ }^{25}$ The boundaries of its external dimension were specified in more detail by holding that an international agreement does not violate the autonomy of EU law if it "clearly separates the Community from the other Contracting Parties from an institutional point of view and no longer affects either the exercise by the Community and its institutions of their powers by changing the nature of those powers, or the interpretation of Community law". ${ }^{26}$ As well as these Opinions, the constitutional doctrine of autonomy has also been reiterated and unfolded in landmark CJEU judgments, notably in the MOX Plant ${ }^{27}$ and the Kadi I rulings. ${ }^{28}$ In these two judgments, the Court revitalized the external dimension of this notion by stating that "an international agreement cannot affect the allocation of responsibilities defined in the Treaties, and consequently, the autonomy of the Community legal system" 29 and strongly emphasised the "internal and autonomous legal order of the Community", ${ }^{30}$ which is not to be prejudiced by international law.

The CJEU later reaffirmed, with particular vigour, the importance of autonomy as a fundamental constitutional principle of EU law in its Opinion 2/13 relating to the compatibility with EU law of the agreement for the accession of the European Union to the ECHR. The specific legal reason why the CJEU has intensely focussed in on autonomy can originally be found in Protocol No 8 to the founding Treaties relating to the general modalities of the accession of the EU to the ECHR. ${ }^{31}$ Some instructions set forth in the Protocol can be conceived, at least implicitly, as the non-judicial pronouncement of this principle. Arts. 1 and 2 stipulate that the EU's accession agreement to the ECHR "shall make provision for preserving the specific characteristics of the Union and Union law [and

23 ECLI:EU:C:1991:490, paras. 30, 35 and 47.

24 Opinion 1/92, Draft agreement between the Community, on the one hand, and the countries of the European Free Trade Association, on the other, relating to the creation of the European Economic Area, Opinion of the Court of 10 April 1992, ECLI:EU:C:1992:189, paras. 17-18, 22, 24, 29, 36; Opinion 1/00, Proposed agreement between the European Community and non-Member States on the establishment of a European Common Aviation Area, Opinion of the Court of 22 April 2002, ECLI:EU:C:2002:231, paras. 5-6, 12, 21, 26-27, 37, 46; Opinion 1/09, Draft agreement - Creation of a unified patent litigation system - European and Community Patents Court, Opinion of the Court (Full Court) of 8 March 2011, ECLI:EU:C:2011:123, paras. 67, 76.

25 Holdgaard (2008) 85.

26 ECLI:EU:C:2002:231, para. 6.

27 Case C-459/03, Commission of the European Communities v Ireland (MOX Plant), Judgment of the Court (Grand Chamber) of 30 May 2006, ECLI:EU:C:2006:345.

28 Joined Cases C-402/05 P and C-415/05 P, Yassin Abdullah Kadi and Al Barakaat International Foundation $v$ Council of the European Union and Commission of the European Communities, Judgment of the Court (Grand Chamber) of 3 September 2008, ECLI:EU:C:2008:461.

29 ECLI:EU:C:2006:345, para. 123., then repeated in Kadi I (ECLI:EU:C:2008:461, para. 282).

30 ECLI:EU:C:2008:461, para. 317.

31 Protocol (No 8) relating to Article 6(2) of the Treaty on European Union on the accession of the Union to the European Convention on the Protection of Human Rights and Fundamental Freedoms (OJ C 326, 26.10.2012, 273). 
the] accession of the Union shall not affect the competences of the Union or the powers of its institutions". Furthermore, Art. 3 orders that the future accession agreement shall not affect Art. 344 of Treaty on the functioning of the European Union (TFEU). The above provisions are a little timidly but unmistakeably circumscribe the concept of autonomy of EU law. Unsurprisingly, the Advocate General and then the EU Court, besides echoing the famous formulae of earlier case-law, have principally deducted the autonomy-related requirements from Protocol No 8. ${ }^{32}$ After the restatement of the classic lines, i.e. that "the founding treaties of the EU, unlike ordinary international treaties, established a new legal order", ${ }^{33}$ the Court then gave an implicit definition of this controversial legal concept. It encapsulated the main features and building blocks of the autonomous nature of the EU legal order by specifying that "the EU has a new kind of legal order, the nature of which is peculiar to the EU, its own constitutional framework and founding principles, a particularly sophisticated institutional structure and a full set of legal rules to ensure its operation". ${ }^{34}$ In the present state of affairs, the EU Court understands autonomy in a way that the Union may be a construction of international law, but in its internal legal order its own rules replace the principles and mechanisms of international law. ${ }^{35}$ Further, in case of norm conflicts between its internal rules (acquis communautaire) and undertaken external obligations (international law binding the EU), primary EU law is given priority over conflicting international agreements and other international obligations. Some of these collision rules are laid down in the founding Treaties, ${ }^{36}$ others have been developed by the European Court of Justice, with regard to certain general principles of EU law. ${ }^{37}$

Borrowing van Rossem's words, the preservation of the "external autonomy" of EU law has been understood by the CJEU, as voiced especially in its Opinions 1/91, 1/92 and $1 / 00,{ }^{38}$ to require two things:

"[f]irst, that the essential character of the powers of the [EU] and its institutions remains unaltered by an international agreement. Secondly, that procedures for ensuring uniform interpretation of treaties, specifically procedures that involve an external judicial body, do not have the effect of binding the EU and its institutions, in the exercise of their internal powers, to a particular interpretation of the rules of EU law". ${ }^{39}$

32 ECLI:EU:C:2014:2475, paras. 105-120, 157-174. (AG opinion); ECLI:EU:C:2014:2454, paras. $157-161,172-174$.

33 ECLI:EU:C:2014:2454, para. 157.

34 ECLI:EU:C:2014:2454, para. 158.

35 Opinion 2/13 of the Court of Justice on Access of the EU to the ECHR - One Step ahead and Two Steps Back. Blog entry of 31 March 2015. See on $<$ http://europeanlawblog.eu $>$ accessed 1 April 2016.

36 Arts. 216(2), 218(11) and 351 TFEU.

37 Case C-122/95, Federal Republic of Germany v Council of the European Union, Judgment of the Court of 10 March 1998, ECLI:EU:C:1998:94; Case C-162/96, A. Racke GmbH \& Co. v Hauptzollamt Mainz, Judgment of the Court of 16 June 1998, ECLI:EU:C:1998:293; Joined Cases C-402/05 P and C-415/05 P, Yassin Abdullah Kadi and Al Barakaat International Foundation v Council of the European Union and Commission of the European Communities, Judgment of the Court (Grand Chamber) of 3 September 2008, ECLI:EU:C:2008:461.

38 For the original appearance of these requirements see ECLI:EU:C:1991:490, paras. 35, 3942; afterwards echoed in subsequent opinions (ECLI:EU:C:1992:189, paras. 17-22, 32, 41; ECLI:EU:C:2002:231, paras. 11-13).

39 van Rossem (2011) 61. See also: Wessel - Blockmans (2013) 8-9. 
As a result of the aforementioned jurisprudential developments, the autonomy of EU law has now been construed in the Luxembourg case-law as a legal concept of constitutional character and was firmly expressed in the flagship judgments of MOX Plant and Kadi I, as well as most recently and overtly in Opinion 2/13. In MOX Plant, the Court once more stressed that "an international agreement cannot affect the allocation of responsibilities defined in the Treaties, and consequently, the autonomy of the Community legal system." 40 In addition to that, in the first judgment rendered by the CJEU in Kadi, which repeated the above passage from MOX Plant, it was also argued that "the review by the Court of the validity of any Community measure [...] must be considered to be the expression $[\ldots]$ of a constitutional guarantee stemming from the EC Treaty as an autonomous legal system". ${ }^{41}$

Similarly, the resurfaced and seemingly stronger constitutional concept of autonomy represented the centre of gravity in the EU Court's reasoning in Opinion 2/13. The highprofile Opinion devoted a sub-section to "the specific characteristics and autonomy of EU law", 42 which summarised the previous case-law on the meaning and content of the autonomy attributed to the Union legal order. The Court further held that "characteristics relating to the constitutional structure of the EU" also include "specific characteristics arising from the very nature of EU law[, in] particular [...] EU law is characterised by the fact that it stems from an independent source of law". ${ }^{43}$ The elevation of the concept of autonomy to the level of the Union's constitutional foundations explains specifically that "[ $\mathrm{t}]$ he autonomy enjoyed by EU law in relation to the laws of the Member States and in relation to international law requires that the interpretation of [...] fundamental rights be ensured within the framework of the structure and objectives of the EU."44

Stressing the autonomy of the EU legal order in this context can also be seen, as some scholars argue e.g., van Rossem, ${ }^{45}$ Koskenniemi, ${ }^{46}$ Burgorgue-Larsen,${ }^{47}$ as a disguised claim to sovereignty. The EU "envies" its Member States in this respect, and autonomy for the EU legal order would be something axiomatic like sovereignty for the national legal systems. Along those lines, EU law can be seen as "a municipal legal order of trans-national dimensions" which description appeared in an Opinion of Advocate General Maduro ${ }^{48}$ and then was apparently endorsed by the CJEU, e.g. in the Kadi I or ATAA ${ }^{49}$ rulings. $^{50}$

40 ECLI:EU:C:2006:345, para. 123.

41 ECLI:EU:C:2008:461, para. 316.

42 ECLI:EU:C:2014:2454, paras. 179-200.

43 ECLI:EU:C:2014:2454, para. 166.

44 ECLI:EU:C:2014:2454, para. 170.

45 van Rossem (2013) 25-27.

46 Koskenniemi (2007) 1.

47 Burgorgue-Larsen (2008) 263 ("[l'autonomie serait] à l'ordre juridique communautaire ce qu'est la souveraineté pour les ordres juridiques nationaux").

48 Opinion of Advocate General Poires Maduro delivered on 16 January 2008 in Case C-402/05 P, Yassin Abdullah Kadi $v$ Council of the European Union and Commission of the European Communities, ECLI:EU:C:2008:11, para. 21.

49 Case C-366/10, Air Transport Association of America and Others $v$ Secretary of State for Energy and Climate Change, Judgment of the Court (Grand Chamber) of 21 December 2011, ECLI:EU:C:2011:864.

${ }^{50}$ In the legal literature, see also Fikfak (2013) 21 (on Kadi I); or Odermatt (2014) 710. (on ATAA). 
Against this backdrop, it can be summarized that the external dimension of the autonomy of EU law, indicating its emancipation from international law, applies in relation to third States and international organisations, including international judicial bodies and also the whole body of general international law. Doctrines that have been elaborated and gradually developed by the CJEU present nicely themselves together through the prism of Opinion $2 / 13$, such as preserving the specific and essential characteristics of EU law as well as the exclusive jurisdiction of the CJEU, or the prohibition of entrusting the judicial review of some of the EU acts to a non-EU body. The EU Court left no doubt about the separation of the two legal orders when postulating that "Security Council resolutions and Council common positions and regulations originate from distinct legal orders". ${ }^{11}$ Nevertheless, the autonomous existence of EU law does not mean that "the Community's municipal legal order and the international legal order pass by each other like ships in the night." 52 The latter has definitely its place and role in the EU normative framework, likewise in national legal orders which accommodate international legal norms pursuant to their own constitutional requirements. EU law and international law are treated theoretically and dogmatically by the Court of Justice as forming two independent and parallel legal orders, which standpoint obviously does not exclude their mutual interactions.

A purely conceptual notion of autonomy as the CJEU has elaborated and heavily relied on in Opinion 2/13 is, in itself, not enough. It cannot exist in isolation, thus there is a need for it to be embedded and concretisation in social reality. ${ }^{53}$ Autonomy merely remains a claim until it is accepted by the international community and other stakeholders on the international plane. ${ }^{54}$ The claimed autonomy of EU law has not only emphasised and advocated by EU lawyers but many international law scholars have also examined EU law's specific, autonomous character and whether it qualifies as a "self-contained regime", as its best or closest example. ${ }^{55}$ Yet, it is still disputed amongst legal scholars whether it is an absolute (fully-fledged self-contained regime-like) or relative autonomy. EU law keeps its umbilical ties with international law as one of its highly specialized sub-system. ${ }^{56}$

Beyond academia, certain external actors in international law, notably international judicial bodies and international organisations have also recognized this self-proclaimed

51 Case C-548/09, Bank Melli Iran v Council of the European Union, Judgment of the Court (Grand Chamber) of 16 November 2011, ECLI:EU:C:2011:735, para. 100. In legal literature, see also Kirchmair (2012) 2012, 678-679.

52 Opinion of Advocate General Poiares Maduro delivered on 16 January 2008, ECLI:EU: C:2008:11, para. 22.

53 See also, Dubout (2012) 26.

54 Similarly, see Louwerse (2015) 74-75.

55 See e.g. Sørensen (1983) 559-576; Simma (1985) 111-136; Weiler (1991) 2403-2484; Conway (2002) 679-695; Simma, Pulkowski (2006) 483-529; Rosas (2008) 255-265.

56 Similarly, see de Witte (2010) 142 or the International Law Commission's 2006 report on the fragmentation of international law (Fragmentation of International Law: Difficulties Arising from the Diversification and Expansion of International Law, Report of the Study Group of the International Law commission, Finalized by Marti Koskenniemi, UN Document A/CN 4/L 682, 13 April 2006, paras. 8, 157, 218-219). Weiler and Haltern draw the attention to that fact that leading international law periodicals such as the American Journal of International Law or the European Journal of International Law do not consider, as a matter of principle, the law of the European Union as international law (Weiler, Haltern (1996) 421-422). 
autonomy of EU law. This is illustrated by the approach taken by the European Court of Human Rights (ECtHR), ${ }^{57}$ and some other arbitral tribunals. The Arbitration Tribunal recognized the EU's special judicial system, including the adjudicative autonomy of the CJEU, in the Belgium/Netherlands (Iron Rhine Arbitration) case. ${ }^{58}$ In the first round of the complicated dispute between Ireland and the United Kingdom concerning the operation of MOX Plant in the Irish Sea, the Arbitral Tribunal constituted pursuant to UNCLOS held that "the problems $[\ldots]$ relate to matters which essentially concern the internal operation of a separate legal order (namely the legal order of the European Communities)." ${ }^{\circ 9}$ It should be noted that the practice of arbitration tribunals varies and the picture is much more complex, with opposing standpoints from an ad hoc tribunal to another. This variation is well illustrated with a recent award rendered by an arbitration tribunal set up under the International Centre for Settlement of Investment Disputes in Electrabel S.A. v. Republic of Hungary, which has plainly qualified EU law as part of international law, being just a subsystem of it. ${ }^{60}$ Furthermore, the position, regarding the attitude of international organisations, favouring the autonomy of EU law has been reflected in the practice of the Council of Europe (CoE) with the invention of the so-called "disconnection clauses" used in many CoE conventions in order not to hinder EU legislative autonomy. ${ }^{61}$ This technique has been followed by other international organisations for agreements drafted under their aegis. ${ }^{62}$ Moreover, the legal solution adopted by the World Trade Organization (WTO), where the EU as a distinct entity - a regional economic integration organization forming a "single customs union" - was admitted as a full WTO member in $1995 .{ }^{63}$ This shows a recognition of the separate nature of EU law from international law, in the eyes of certain actors within the international legal sphere.

57 Mousaquim v Belgium (application no. 12313/86), Judgment of 18 February 1991, para. 49; where EU law is referred to as a "special legal order". See also this approach in Matthews v. United Kingdom (application no 24833/94), Judgement of 18 February 1999.

58 Permanent Court of Arbitration, Belgium/Netherlands ("Iron Rhine Arbitration"), Award of the Arbitral Tribunal of 24 May 2005, paras. 101-103.

59 Arbitral Tribunal Constituted Pursuant to Article 287, and Article 1 of Annex VII, of UNCLOS for the Dispute Concerning the MOX Plant, International Movements of Radioactive Materials, and the Protection of the Marine Environment of the Irish Sea, Ireland v United Kingdom (The MOX Plant case), Order No. 3 of 24 June 2003, para. 24.

${ }^{60}$ Electrabel S.A. v. Republic of Hungary, ICSID Case No. ARB/07/19, Decision on Jurisdiction, Applicable Law and Liability of 30 November 2012, paras. 4.119-4.123.

${ }^{61}$ For a comprehensive account of this practice, with numerous examples, see Council of Europe, Committee of Ministers, Doc. CM(2008)164, 1044 Meeting, 10 December 2008, point 10 Legal Questions, 10.6 Committee of Legal Advisers on Public International Law (CAHDI) c. Report on the consequences of the so-called "disconnection clause" in international law in general and for the Council of Europe Conventions, containing such a clause in particular. For more academic analysis, see e.g. Kolliopoulos, Economides (2006) 273-302; Ličková (2008) 463-490; Cremona (2010) 160186.

${ }^{62}$ For instance, the UN Economic Commission for Europe (UNECE) drafted a Protocol on Civil Liability for Damage Caused by the Transboundary Effects of Industrial Accidents on Transboundary Waters, or the Convention concerning International Carriage by Rail (COTIF), both containing such disconnection clauses.

${ }^{63} \mathrm{See}<\mathrm{https}: / /$ www.wto.org/english/thewto_e/countries_e/european_communities_e.htm $>$ accessed 1 April 2016. 


\section{PRESERVING THE AUTONOMY OF EU LAW VIS-À-VIS INTERNATIONAL LAW: LEGAL TECHNIQUES, SUBSTANTIVE REQUIREMENTS AND CHALLENGES}

The preliminary issue of what is a "legal order" arises when discussing the autonomy of EU law from the perspective of the international legal order. The appearance of the idea of a legal order is a fairly recent one and Pierre-Marie Dupuy highlights that the first commentators to invoke this idea emerged in German public law in the first half of the 19th century, who were the successors of the political philosophy of Kant, Hegel and Schelling. The concept of legal order (Rechtsordnung) was developed in tandem with the theory of rule of law (Rechtsstaat), with which it is frequently associated, and it referred to as an organic and structural normative whole. ${ }^{64}$ The usage of the term "legal order" appears to be fairly technical, yet Timsit described it as also having a metaphorical role. ${ }^{65}$ The notion of legal order is a representation seeking to conceive the functioning of law. ${ }^{66}$ There is extremely abundant legal literature ${ }^{67}$ on the meaning of "legal order" so it is sufficient to briefly highlight the common elements identified in scholarly writings. These elements encompass, inter alia, the autonomous regime of validity; own sources of law; selfreferential nature; and specific mechanisms guaranteeing the unity of interpretation of the rules belonging to the system. On the basis of those distinctive features, legal order can be defined as an organized body of legal norms along a certain logic and structural principles. It is more than just a conglomerate of legal rules, and governing the concrete, real functioning of social, economic etc. relations and interactions hence its impact on social reality (effectiveness) matters. Pierre-Marie Dupuy also concludes that although conceptions of a legal order vary significantly between authors, all agree that the expression refers to the organisation of a more or less complex system of norms and institutions intended effectively to apply to the constitutive subjects of a determined community. ${ }^{68}$

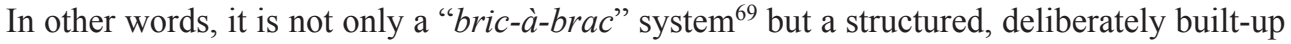
system. Moreover, its self-referential character is to be red-flagged, since through this feature a legal order is able to maintain its unity and its own existence. ${ }^{70}$

The EU's self-perception regarding its own legal framework appeared in the first preliminary ruling where the CJEU described Community law as a "legal order". ${ }^{71}$ The Court did not dig deep in explaining which mechanisms are required so that a legal order emerges and what the belonging of norms to a given system of law means. It just plainly

64 Dupuy (2007) 1.

65 Timsit (2001) 3-18.

66 Dubout (2012) 24.

${ }^{67}$ For a good summary of the relevant scholarly writings, see e.g. Barents (2004) 170-171. (footnotes 19-20).

68 Dupuy (2006) paras. 15-27.

69 This term was used by Jean Combacau in relation to international law when he assessed whether the law of nations is a genuine system or just a random aggregation of norms of international origin (Combacau (1986) 88-105).

70 Barents (2004) 171.

${ }^{71}$ Case 13-61, Kledingverkoopbedrijf de Geus en Uitdenbogerd v Robert Bosch GmbH and Maatschappij tot voortzetting van de zaken der Firma Willem van Rijn, Judgment of the Court of 6 April 1962, ECLI:EU:C:1962:11. 
stated that the law stemming from the Treaties and that made by the Community institutions qualify as a legal order. The original version of the 1957 Treaty establishing the European Economic Community (TEEC) had not contained such a reference to the "Community legal order, but this expression was later inserted into Art. 227 TEEC, due to subsequent treaty modifications, in connection with the situation of the outermost regions (Art. 299 using the Treaty of Amsterdam new numbering). In the present state of affairs, a reference to the "Union legal order" can be found in Art. 349 TFEU, ${ }^{72}$ thereby continuously providing a solid positive law foundation of the term. Assuming that EU law constitutes a legal order, it means that it cannot be subject to other external legal orders, thus it is self-standing and the source of validity of its rules (concerns secondary EU law) can be found within this specific normative system (self-referential character).The requirements, which have been elaborated either by the EU legislator or the Court of Justice, to make this claim for being an autonomous legal order will be explored below.

In order to make the self-perceived autonomy reality, it is indispensable to elaborate various legal techniques and substantive requirements to preserve the autonomous character and functioning of EU law from international law. The preservation of the external dimension of autonomy is essentially based on two requirements: The essential character of the powers of the Union and its institutions as conceived in the founding Treaties remain unaltered by international (treaty) law, and that the procedures for ensuring uniform interpretation of such an international agreement and for resolving disputes with other contracting parties will not have the effect of binding the EU and its institutions, in the exercise of their internal powers, to a particular interpretation of the rules of Union law referred to in that agreement. ${ }^{73}$ The following analysis is conducted against this backdrop, reflecting on various manifestations of these preconditions in codified law and jurisprudence. CJEU case-law gives the most helpful indications as the concept of (external) autonomy has never been mentioned in EU primary law.

However, it is still worth beginning with black letter law because there are some essential provisions in the founding Treaties that protect the specificity and integrity of the EU legal order, mainly from external influences. Art. 344 TFEU is such a clause that enshrines the exclusive and compulsory jurisdiction of the EU Court in the following terms:

Member States undertake not to submit a dispute concerning the interpretation or application of the Treaties to any method of settlement other than those provided for therein.

This essential principle and self-limitation for Member States relating to their external action had been recalled by the Court decades ago (for instance in Opinions 1/91 and 1/00). ${ }^{74}$ It has also been understood as a specific expression of Member States' duty of sincere cooperation (loyalty) enshrined in Art. 4(3) of the Treaty on European Union (TEU) since the MOX Plant case. ${ }^{75}$ It flows from the Luxembourg jurisprudence that dispute settlement procedures involving an external judicial body e.g. the Court of the European Economic Area, the WTO Dispute Settlement Bodies, or the European Court of Human Rights, shall not affect the powers of CJEU and the uniform, authentic interpretation of EU

72 "The Council shall adopt measures $[\ldots]$ without undermining the integrity and the coherence of the Union legal order..." (emphasis added - T.M.).

73 Summarized together in Opinion 1/00, ECLI:EU:C:2002:23, paras.12-13.

${ }^{74}$ See also e.g. Gautron (2000) 24.

75 ECLI:EU:C:2006:345, para. 169. 
law. Van Rossem stated that the "European legal order possessed an inner core - in particular the EC's unique judicial structure - that, save for treaty amendment, could not be touched by international law." $" 76$

The freshest and manifest expression of this requirement, - besides MOX Plant - the previous leading case in the regard, has surfaced in Opinion 2/13. Here, the Court examined the ramifications of Art. 344 TFEU and shed more light on the boundaries between lawful and unlawful external judicial control over EU law by an international court. It was set out, as a matter of principle, that an international agreement cannot affect the autonomy of the EU legal system and the respective powers of the Court - a principle enshrined in Art. 344 TFEU. This provision is specifically intended to preserve the exclusive nature of the procedure for settling those disputes within the EU and in particular of the jurisdiction of the Court of Justice in that respect, thus precluding any prior or subsequent external control. ${ }^{77}$ However, the EU Court also restated its previous dictum that the creation of an external judicial body whose decisions are binding on the EU institutions, including the Court of Justice, is not, in principle, incompatible with EU law. ${ }^{78}$ This is particularly the case where the conclusion of such an agreement is provided for by the Treaties themselves, see Art. 6(2) TEU laying down the obligation of the EU to accede to the ECHR. ${ }^{79}$ Upon a closer inspection of the evolution of this case-law, it can be observed that originally Art. 344 TFEU has just been mentioned en passant in the CJEU autonomy-related pronouncements e.g., in Opinion 1/91. The shift was brought by MOX Plant, which not only reaffirmed it as a manifestation of the autonomous nature of EU law, but discussed it more at length. By virtue of the judgment, given that the treaty at hand, the United Nations Convention on the Law of the Sea (UNCLOS) ${ }^{80}$ makes it possible that the dispute resolution system under EU law takes precedence over the system established by Part XV of UNCLOS and the breach of the EU Court's exclusive jurisdiction under Art. 344 TFEU has been avoided. ${ }^{81}$ Here the threshold for complying with Art. 344 TFEU is the possibility of Member State compliance. ${ }^{82}$ However, the CJEU opted for a different reasoning in relation to another mixed agreement (the ECHR) setting up an inter-party judicial dispute settlement mechanism (the ECtHR) in Opinion $2 / 13$ by raising the bar of compliance. The Court declared that the very existence of a possibility to bring inter-States disputes before the Strasbourg Court is liable in itself to undermine the objective of Art. 344 TFEU $^{83}$ and goes against the very nature of EU law. ${ }^{84}$ Consequently, "only the express exclusion of the ECtHR's jurisdiction [...] over disputes between the Member States or between the Member

76 Van Rossem (2013) 16.

77 ECLI:EU:C:2014:2454, para. 210.

78 ECLI:EU:C:2014:2454, para. 182; previously see in Opinion 1/91, EU:C:1991:490, paras. 40, 70, and Opinion 1/09, ECLI:EU:C:2011:123, para. 74.

79 "The Union shall accede to the European Convention for the Protection of Human Rights and Fundamental Freedoms. Such accession shall not affect the Union's competences as defined in the Treaties."

${ }^{80}$ United Nations Convention on the Law of the Sea, signed on 10 December 1982 in Montego Bay, UNTS No. 31263, Vol. 1883, 3.

81 ECLI:EU:C:2006:345, para. 124-125.

82 Johansen (2015) 174.

83 ECLI:EU:C:2014:2454, para. 208.

84 ECLI:EU:C:2014:2454 ,paras. 207, 212-124. 
States and the EU in relation to the application of the ECHR within the scope ratione materiae of EU law would be compatible with Art. 344 TFEU". ${ }^{85}$ As a result, the Court of Justice set a stricter limitation, clearly at odds with its earlier position in MOX Plant, whereby the Member States cannot even be given a theoretical possibility of breaching the Treaty article laying down the exclusive and compulsory jurisdiction of the CJEU. ${ }^{86}$

In a likewise manner, Art. 351 TFEU further embodies an important guarantee in order to shield the autonomous legal order of the Union from international law, mainly from external treaty obligations. According to this provision, [t] he rights and obligations arising from agreements concluded before 1 January 1958 or, for acceding States, before the date of their accession, between one or more Member States on the one hand, and one or more third countries on the other, shall not be affected by the provisions of the Treaties.

To the extent that such agreements are not compatible with the Treaties, the Member State or States concerned shall take all appropriate steps to eliminate the incompatibilities established. Member States shall, where necessary, assist each other to this end and shall, where appropriate, adopt a common attitude.

In applying the agreements referred to in the first paragraph, Member States shall take into account the fact that the advantages accorded under the Treaties by each Member State form an integral part of the establishment of the Union and are thereby inseparably linked with the creation of common institutions, the conferring of powers upon them and the granting of the same advantages by all the other Member States. (emphasis added - T.M)

The rationale behind this conflict rule is twofold. ${ }^{87}$ The first is that it represents an escape clause for some pre-Community/Union international agreements concluded by Member States with third parties. In this sense, Art. 351(1) TFEU protects third States' reliance interests that their agreements with EU Member States can stand, from the perspective of EU law, in accordance with the international law principle pacta tertiis nec nocent nec prosunt. The other rationale is that Art. 351 TFEU was crafted to gently and gradually eliminate conflicting agreements with the founding Treaties. ${ }^{88}$ As for the first, traditional function of this treaty provision, the EU Court drew the boundaries of the exception protecting third parties' rights in the 2008 Kadi I judgment when it explained that Art. 351 TFEU "does not apply when at issue are the principles of liberty, democracy and respect for human rights and fundamental freedoms enshrined in [the Treaty] as a foundation of the Union" 89 and likewise it "may under no circumstances permit any challenges to the principles that form part of the very foundations of the Community legal order". ${ }^{90}$ Thus in the post-Kadi period, this conflict rule has sharper teeth in protecting the autonomous nature of the EU legal order, allowing for much narrower derogations from primary law via Member States' international obligations undertaken before the creation of/accession to the European Union (or its predecessors). In a similar manner, recent approaches of the European Commission, then the EU co-legislators e.g. requiring the termination of bilateral investment treaties (BITs) between EU Member States and third States which are in conflict

85 ECLI:EU:C:2014:2454, para. 213.

86 See also Johansen (2015) 170, 175.

87 See e.g. Léger (2000) 1937-1944 (Art. 307).

88 For more on the significance and implications of this treaty provision, see Klabbers (2009)

89 ECLI:EU:C:2008:461, paras. 301 and 303.

90 ECLI:EU:C:2008:461, para. 304. 
with EU law, ${ }^{91}$ point to the same direction. These attempts are about restricting the first function of Art. 351 TFEU, i.e. its non-affection clause character for international obligations undertaken towards third parties, and stressing its second function, thus shielding the autonomy of EU law from international law. The mentioned trends in caselaw and in the practice of EU Institutions are not the only indicators towards the less international law-friendly approach.

A further sign of the strengthening the autonomy of EU law via conflict rules can be detected in the post-new millennium EU-accession treaties, notably in the Acts of Accession of 2003, 2005 and 2011. These primary law instruments, having the same legal value as the founding Treaties, have set even stricter obligations than Art. 351(2) TFEU for the new Member States that joined the EU during the last three rounds of accessions, encompassing altogether thirteen new members. ${ }^{92}$ For instance, Art. 6(10) of the 2003 Act of Accession ${ }^{93}$ stipulates as follows:

To the extent that agreements between one or more of the new Member States on the one hand, and one or more third countries on the other, are not compatible with the obligations arising from this Act, the new Member State shall take all appropriate steps to eliminate the incompatibilities established. If a new Member State encounters difficulties in adjusting an agreement concluded with one or more third countries before accession, it shall, according to the terms of the agreement, withdraw from that agreement." (emphasis added - T.M.)

The last phrase of this provision makes it clear that the ten Member States that joined the Union in 2004 could only honour their obligations flowing from EU law by denouncing (withdrawing from) the conflicting international agreements (a "shall clause"). The subsequent Acts of Accession contain an almost identical clause, ${ }^{94}$ which shows that this method has steadily ingrained in primary law to protect the autonomy of EU law with respect to new Member States international obligations with third partners predating their EU membership.

This jurisprudence is far richer than codified EU law as far as the requirements of preserving the autonomy of EU law elaborated by the CJEU are concerned. As the EU Court first stressed in Opinion 1/91, then in the MOX Plant and Kadi I cases, the essential

91 See the proposal for a Regulation establishing transitional arrangements for bilateral investment agreements between Member States and third countries (COM(2010)344 final, Brussels, 7.7.2010), which aimed at, inter alia, empowering Member States to amend BITs in order to remove incompatibilities with EU law. The legal act was finally adopted as Regulation (EU) No 1219/2012 of the European Parliament and of the Council of 12 December 2012 (OJ L 351, 20.12.2012, 40-46.). As for academic commentaries of the new approach, see e.g. Terhechte (2011) 79-93.

92 Bartha (2015) 110-112.

932003 Act concerning the conditions of accession of the Czech Republic, the Republic of Estonia, the Republic of Cyprus, the Republic of Latvia, the Republic of Lithuania, the Republic of Hungary, the Republic of Malta, the Republic of Poland, the Republic of Slovenia and the Slovak Republic and the adjustments to the Treaties on which the European Union is founded (OJ L 236, 23.9.2003, 17-930).

942005 Protocol concerning the conditions and arrangements for admission of the Republic of Bulgaria and Romania to the European Union, Art. 6(10) (OJ L 157, 21.6.2005, 29-202.); and 2011 Act concerning the conditions of accession of the Republic of Croatia and the adjustments to the Treaty on European Union, the Treaty on the Functioning of the European Union and the Treaty establishing the European Atomic Energy Community, Art. 6(9) (OJ L 112, 24.4.2012, 6-110.). 
characters of EU powers, the allocation of competences and responsibilities of institutions defined in the founding Treaties shall be unaltered by subsequent international agreements. It is interesting to see the evolution of this jurisprudence, slowly but surely enlarging the scope of those requirements to different kinds of international obligations. First, in Opinion $1 / 91$ a specific category of international treaties was at stake (the first version of the EAA Agreement), which contained substantive rules having been almost identical to norms of Community law and which was meant to transplant some aspects of the Community model to the international plane as well as to create an international (regional) court to supervise that. Similar agreements have then been drafted relating to the establishment of a European Civil Aviation Area and the European and Community Patents Courts, both of which triggered Opinions of the CJEU that echoed the same requirements (Opinions 1/00 and 1/09). The next level was reached with the MOX Plant case, where the treaty at issue was totally different from the previous international instruments. ${ }^{95}$ It was a multilateral treaty of universal character, UNCLOS, to which the European Community (now European Union) is also a party, alongside with Member States. This is a "mixed agreement" from the perspective of EU treaty practice. This character of the UNLCOS, however, did not prevent the CJEU from invoking the autonomy of EU law. It first echoed previous jurisprudence that an "international agreement cannot affect the allocation of responsibilities defined in the Treaties". The Court then concluded that it could not tolerate the "manifest risk that the jurisdictional order laid down in the Treaties and, consequently, the autonomy of the Community legal system may be adversely affected." 96

Finally, in the first Kadi judgment (2008), the judges in Luxemburg further expanded the eventual scenarios where the external dimension of autonomy comes into play. The case was peculiar in the sense that neither is the EU a member of the United Nations (UN) or an addressee of UN Security Council resolutions adopted under Chapter VII of the UN Charter (in absence of an international obligation binding the Union), nor was there a competing jurisdiction of another international court with that of the CJEU. At this time, it was not actually the need to protect the competences of the institutions, including the Court's exclusive jurisdiction from external actors that triggered the recourse to the "autonomy argument", but a more general and more profound concern for the constitutional integrity of the EU legal order ${ }^{97}$ - notably the protection of fundamental rights and the rule of law, including the judicial review of Union acts in all circumstances by the CJEU. As a result, autonomy as a constitutional principle is not only opposed to international treaties and other international obligations binding on the EU, but it was stretched beyond that circle and is applied to the whole body of international law, regardless of its binding force on and legal effects towards the European Union. Some commentators assess it extremely far-reaching, ${ }^{98}$ even the then Court of First Instance (now General Court) expressed its scepticism in the 2010 Kadi II decision: "the Court of Justice thus seems to have regarded the constitutional framework created by the EC Treaty as a wholly autonomous legal order, not subject to the higher rules of international law - in this case the law deriving from the Charter of the United Nations." $" 99$

95 Also noticed by van Rossem (2013) 16.

96 ECLI:EU:C:2006:345, paras. 123 and 154.

97 van Rossem (2013) 17.

98 See e.g. de Búrca (2010) 1-49; Dubout (2012) 29.

99 Case T-85/09, Yassin Abdullah Kadi v European Commission, Judgment of the General Court (Seventh Chamber) of 30 September 2010, ECLI:EU:T:2010:418, para. 119. 
No matter how far the CJEU seems to have gone, returning to the basics, in terms of the origins and existence of the EU legal order, shows that even the position taken by the Court of Justice in Kadi I can be considered logical and somehow necessary. It should be admitted that the prime rationale behind autonomy of EU law is to separate and distinguish it from international law as much as possible. EU law has originally been created within the realm of international law and the "fatherhood" of the latter can never be denied. EU's legal architecture was and is still founded on ordinary international treaties governed by the international law of the treaties. The autonomy of the EU legal order represents, using Schilling's words, a sort of "derivative autonomy" 100 which means the there is another legal order in relation to which this autonomy is claimed and its degree is assessed. Once it has been set up, it is independent from the contents of the original legal order, that is general international law. By contrast, the autonomous character of the national legal orders goes without saying. It is uncontested and does not need any justification at all as widespread domestic and international practice indicates so. Some refer to it as "original autonomy"101 indicating that the national legal systems are ultimately created by their original constituent powers and they possess their own internal source of legitimacy, paired with their independent and self-constructed regime of validity. They are $a b$ ovo distinct from each other and, at least from the dualistic point of view, from the international legal order as well. According to the voluntarist theory, the latter is the creation of the formers. But owing to the fact that EU law is undeniably rooted in international law, this quest for autonomy was, naturally, first and foremost directed towards the original framework of reference, the international legal order, and it resembled a "like father like son" situation. It can be summarised as a going in a full circle: The more extreme position is taken by the EU Court, the more likely this emancipation could effectively be realized and be endorsed by the international community and other external actors.

\section{CONCLUSIONS AND OUTLOOK}

The intrinsically linked external and internal aspects of autonomy have been in the forefront with different intensity throughout various periods of the European integration process. Following the foundational period of the 1960s when the external aspect had first been emphasized by the CJEU in order to parallel claim it internally, towards Member State law, the internal aspect of the concept become dominant for a while during which EU legal order consolidated and got more robust. Along with the constitutionalisation of the EU legal order after the 1990s, and triggered by the EU's increasing and expanding activities on the international plane, the external dimension of autonomy was put again in the focus in the CJEU jurisprudence and academic discourse, which has culminated in Opinion 2/13. The reemerged debates around autonomy of EU law in the international dimension after Opinion 2/13 have correspondingly demonstrated the uncertainties about the legal nature of the EU as an international organization and the specificity or peculiarity of its legal order.

100 Schilling (1996) 389-390. Pernice introduced the category of "embedded autonomy" in the context of EU law, highlighting its relative and not absolute character towards both national legal systems and international law. He submits that "it must be open and accommodate [...] to normative claims and limitations originating from national constitutions as well as from internationally recognised principles" (Pernice (2013) 80).

101 Schilling (1996) 389. 
These blurred lines in the EU legal architecture were powerfully described by Maduro: although "its body is well known, its soul is still to a large extent a mystery" ${ }^{102}$

The recent trends in the CJEU jurisprudence, notably the Kadi I judgment and Opinion $2 / 13$ show a more separated, dualist approach towards international law and in parallel a forceful claim for autonomy from the external legal orders. Nevertheless, the EU Court's overall approach is all but consistent, making outcome-oriented and selective use of international law. ${ }^{103}$ A newly found focus on the external dimension of autonomy "provides an 'easy way out' of unwanted influences, a quick fix for what are perceived to be legitimate decisions in individual cases without regard for overall coherence", argued Ziegler. ${ }^{104}$ All the more, the ECHR-rooted Strasbourg Court, with the firmly-established and robust system of the protection of human rights in Europe, is the Luxembourg Court's principle competitor in a field that is of outstanding relevance for the constitutionalisation of the European integration polity. Therefore the above quotation is even more true when it comes to the EU's institutionalized relations to the ECHR system. Without a crystal ball, foreseeing the future is not an easy task, but the current state of affairs seems to be just an unfinished symphony. Further international agreements of great significance, coupled with monitoring bodies, appear on the horizon to which the Union plans to accede ${ }^{105}$ and these might also entail compatibility issues with EU law, and thus can trigger constitutional challenges where the final word might be said by the CJEU.

All in all, more than fifty years after its foundation, at a time of constitutionalisation of the supranational public authority called EU as well as the intensification and continuous growth of EU external relations, the significance of the concept of autonomy in the EU legal architecture is not to be underestimated. 'Autonomy' has been simply coded in its legal DNA. Emphasizing it externally, towards international law gives the impression "to reinforce a move away from an ordinary intergovernmental organisation on a continuum toward a statist paradigm". ${ }^{106}$ Let us hope that in the future more EU and international law scholars will keep an eye on this very concept. If nothing else, Opinion 2/13 has planted the seeds for prospective in-depth academic discourses on the multifaceted fundamental concept called "autonomy of EU law". 107

102 Maduro (1999) 8.

103 Ziegler (2011).

104 Ziegler (2011) 314.

105 Such as the Council of Europe Convention on the Prevention of Terrorism (CETS No. 196) and the Additional Protocol to the Council of Europe Convention on the Prevention of Terrorism (CETS No. 217) (see the Commission Work Programme 2016, COM(2015) 610 final, Strasbourg, 27.10.2015, especially the proposals in the "List of Planned Commission Initiatives" at $<\mathrm{http} / / \mathrm{ec}$. europa.eu/atwork/pdf/planned_commission_initiatives_2016.pdf> accessed on 1 April 2016), or the Council of Europe Convention on preventing and combating violence against women and domestic violence ("Istanbul Convention") (CETS No. 210). See the proposal on accession at $<\mathrm{http}$ ://ec.europa. eu/justice/gender-equality/files/com_2016_111_en.pdf $>$ accessed on 1 April 2016, as well as the accession of the EU to the 1951 Geneva Convention relating to the Status of Refugees has been repeatedly envisaged since the Stockholm Programme (see e.g. the European Union Declaration on the 60th Anniversary of the 1951 Convention Relating to the Status of Refugees, adopted at the 3121st Justice and Home Affairs Council meeting in Luxembourg, 27-28 October 2011, para. 5).

106 Ziegler (2011) 315.

107 The first swallow of it in English is Ziegler (2011). 


\section{LITERATURE}

Barents, R., The Autonomy of Community Law (Kluwer Law International 2004).

Bartha, I., Nemzetközi szerzödések mozgásban. Alkotmányos és nemzetközi jogi kihivások az Európai Unió külkapcsolataiban (Dialóg Campus 2015).

Benlolo-Carabot, M., Candas, U, Cujo, E. (eds), Union européenne et droit international. En l'honneur de Patrick Daillier (Editions A. Pedone 2012).

Berke, B., 'Az európai közösségi jogrend strukturális elveiről' in M Király (ed), Ius Privatum Ius Commune Europae. Liber amicorum Ferenc Mádl dedicata (ELTE ÁJK Nemzetközi Magánjogi Tanszék 2001) 33-54.

de Búrca, G., 'The European Court of Justice and the International Legal Order After Kadi' (2010) 51 Harvard International Law Journal 1-49.

Burgorgue-Larsen, L., 'Existe-t-il une approche européenne du droit international?' in Fatin RougeStefanini (ed), SFDI, Journée franco-allemande. Droit international et diversité des cultures juridiques (Editions A. Pedone 2008) 257-276.

Cannizzaro, E., Palchetti, P., Wessel, R.A (eds), International law as law of the European Union (Martinus Nijhoff Publishers 2011).

Combacau, J., 'Le droit international: bric-à-brac ou système' (1986) 31 Archives de philosophie du droit, 88-105.

Conway, G., 'Breaches of EC Law and the International Responsibility of Member States', (2002) 13 European Journal of International Law 679-695.

Cremona, M., 'Disconnection Clauses in EC Law and Practice' in CH Hillion, P Koutrakos (eds), Mixed Agreements Revisited: The EU and its Member States in the World (Hart Publishing 2010) 160-186.

Cremona, M., de Witte, B. (eds), EU Foreign Relations Law - Constitutional Fundamentals (Hart Publishing 2008).

Czuczai, J., 'The autonomy of the EU legal order and the law-making activities of international organizations. Some examples regarding the Council most recent practice', (2012) 31 Yearbook of European Law 452-472.

Dashwood, A., Maresceau, M. (eds), Law and Practice of EU External Relations. Salient Features of a Changing Landscape (Cambridge University Press 2011).

Dubout, E., 'La relativité de la distinction des normes du droit de l'Union européenne et du droit international', in L de Burgorgue-Larsen, E Dubout, A Maitrot de la Motte, S Touzé (eds), Les interactions normatives. Droit de l'Union européenne et droit international (Editions A. Pedone 2012) 17-51.

Dubout, E., 'Une question de confiance: nature juridique de l'Union européenne et adhésion à la Convention européenne des droits de l'homme', Revue des Droits et Libertés Fondamentaux (chron. n. 09 2015) at <http://www.revuedlf.com/droit-ue/une-question-de-confiance-naturejuridique-de-lunion-europeenne-et-adhesion-a-la-convention-europeenne-des-droits-de-lhomme/> accessed 1 April 2016.

Dupuy, P.M., 'A Doctrinal Debate in the Globalisation Era: On the "Fragmentation" of International Law' (2007) 1 European Journal of Legal Studies 25-41.

Dupuy, P.M., Droit international public (8th edn Précis Dalloz 2006).

Eckhout, P., EU External Relations Law ( $2^{\text {nd }}$ edn Oxford University Press 2011).

Eckhout, P., 'Opinion 2/13 on EU Accession to the ECHR and Judicial Dialogue - Autonomy or Autarky?' Jean Monnet Working Paper 01/15.

Fikfak, V., 'Kadi and the Role of the Court of Justice of the European Union in the International Legal Order' (2013) 15 Cambridge Yearbook of European Legal Studies 587-617.

Gautron, J-C., Grard, L., 'Rapport général: Le droit international dans la construction de 1'Union européenne' in SFDI, Colloque de Bordeaux. Droit international et droit communautaire, perspectives actuelles (Editions A. Pedone 2000) 11-152.

Holdgaard, R., External Relations Law of the European Community: Legal Reasoning and Legal Discourses. (Kluwer Law International 2008).

Johansen, S. O., 'The reinterpreparation of TFEU Art. 344 in Opinion 2/13 and Its Potencial Consequences' (2015) 16 German Law Journal 169-178. 
Kaddous, Ch., 'Effects of International Agreements in the EU Legal Order', in M Cremona, B de Witte (eds), EU Foreign Relations Law - Constitutional Fundamentals (Hart Publishing 2008) 291-313.

Klabbers, J., Treaty Conflict and the European Union (Cambridge University Press 2009).

Kirchmair, L., 'The 'Janus Face' of the Court of Justice of the European Union: A Theoretical Appraisal of the EU Legal Order's Relationship with International and Member State Law', (2012) 4 Goettingen Journal of International Law 678-679.

Kolliopoulos, A. G., Economides, C. P., 'La clause de déconnexion en faveur du droit communautaire: une pratique critiquable' (2006) 110 Revue Générale de Droit International Public 273-302.

Koskenniemi, M., 'International Law: Constitutionalism, Managerialism and the Ethos of Legal Education' (2007) 1 European Journal of Legal Studies 8-24.

Kuijper, P. J., 'Customary international law, decisions of international organisations and other techniques for ensuring the respect for international legal rules in European Community law', in J Wouters, A Nollkaemper, E de Wet (eds), The Europeanisation of International Law. The Status of International Law in the EU and its Member States (T.M.C. Asser Press 2008) 87-106.

Láncos P.L., 'A Bíróság 2/13. számú véleménye az Unió EJEE-hez való csatlakozásáról', (2015) 1 Pázmány Law Working Papers.

Léger, Ph. (ed), Commentaire article par article des traités UE et CE, (Helbing et Lichtenhahn 2000).

Ličková, M., 'European Exceptionalism in International Law' (2008) 19 European Journal of International Law 463-490.

Louis, J. V. et al, Relations extérieures - Commentaire J. Mégret. Le droit de la CE et de l'Union européenne (Éditions de l'Université de Bruxelles 2005).

Louwerse, L.B., 'The Doctrine of Implied Powers in EU and International Law: Points of Convergence and Divergence' in S Besson, N Levrat, N. (eds), L'Union europeénne et le droit international the European Union and International Law (Shulthess Éditions Romandes 2015) 67-90.

Maduro, M.P., We the Court (Hart Publishing 1999).

Mendez, M., The Legal Effects of EU Agreements (Oxford University Press 2013).

Mohay, Á., 'A nemzetközi jog és az uniós jog kapcsolódási pontjai' (2014) 1 Scriptura 269-281.

Mohay, Á., 'Back to the Drawing Board? Opinion 2/13 of the Court of Justice on the Accession of the EU to the ECHR - Case note' (2015) 2 Pécs Journal of International and European Law 29-36.

Odermatt, J., 'A Giant Step Backwards? Opinion 2/13 on the EU's Accession to the European Convention on Human Rights Leuven Centre for Global Governance Studies Working Paper (No. 150 February 2015).

Odermatt, J, 'The Court of Justice of the European Union: International or Domestic Court?' (2014) 3 Cambridge Journal of International and Comparative Law 696-718.

Pernice, I., 'The Autonomy of the EU Legal Order - Fifty Years After Van Gend', in A Tizzano, J Kokott, S Prechal, S. (eds), 50ème Anniversaire de l'arrêt/50th anniversary of the judgment in Van Gend en Loos, 1963-2013, Actes du Colloque Luxembourg, 13 mai 2013 - conference proceedings Luxembourg, 13 May 2013, Luxembourg, Office des publications de l'Union européenne, 2013, 55-80.

Pescatore, P., 'Van Gend en Loos, 3 February 1963 - A View from Within', in MP Maduro, L Azulai (eds), The Past and Future of EU Law. The Classics of EU Law Revisited on the 50th Anniversary of the Rome Treaty (Hart Publishing 2010) 3-8.

Rosas, A., 'Relations entre les Etats membres de l'Union européenne: le droit international public y a-t-il encore sa place?', in F Alabrune et al. (ed), L'Etat souverain dans le monde d'aujourd'hui. Mélanges en l'honneur de J.-P. Puissochet, (Éditions A. Pedone 2008) 255-265.

van Rossem, J. W., 'The Autonomy of EU Law: More is Less?', in RA Wessel, S Blockmans (eds), Between Autonomy and Dependence. The EU Legal Order Under The Influence of International Organisations (T.M.C. Asser Press/Springer 2013) 13-46.

van Rossem, J. W., 'The EU at crossroads: a constitutional inquiry into the way international law is received within the EU legal order' in E Cannizzaro, P Palchetti, RA Wessel (eds), International law as law of the European Union (Martinus Nijhoff Publishers 2011) 59-89.

Schilling, T., 'The Autonomy of the Community Legal Order: An Analysis of Possible Foundations' (1996) 37 Harvard International Law Journal 389-409.

Simma, B., 'Self-Contained Regimes' (1985) 16 Netherlands Yearbook of International Law 111-136. 
Simma, B., Pulkowski, D., 'Of Planets and the Universe: Self-contained Regimes in International Law' (2006) 17 European Journal of International Law 483-529.

Sørensen, M., 'Autonomous Legal Orders: Some Considerations Relating to a Systems Analysis of International Organisations in the World Legal Order' (1983) 32 International and Comparative Law Quarterly 559-576.

Szabó, M., 'Az európai jog és a nemzetközi jogrend - hierarchia és összefonódás’ (2012) 53 Államés Jogtudomány 191-211.

Szurek, S., 'Du particularisme à l'autonomie? Esquisse des rapports du droit international et du droit communautaire' (2007) 5 Annuaire de droit européen 57-92.

Terhechte, J.P., 'Article 351 TFEU: The Principle of Loyalty and the Future Role of the Member States' Bilateral Investment Treaties' in CH Herrmann, JP Terhechte (eds), European Yearbook of International Economic Law 2011 (Springer 2011) 79-93.

Timsit, G., 'L'ordre juridique comme métaphore' (2001) 33 Droits 3-18.

Troper, M., 'La constitution comme système juridique autonome' (2002) 35 Droits 63-78.

Tsagourias, N., 'Conceptualizing the autonomy of the European Union' in R Collins, ND White (eds), International Organizations and the Idea of Autonomy. Institutional Independence in the International Legal Order (Routledge 2011) 339-351.

van Voren, B., Wessel, R. A., EU External Relations Law. Text, Cases and Materials (Cambridge University Press 2014).

Weiler, J. H. H., 'The Transformation of Europe' (1991) 100 Yale Law Journal 2403-2484.

Weiler, J. H. H., Haltern, U. R., 'Autonomy of the Community Legal Order - Through the Looking Glass' (1996) 37 Harvard International Law Journal 421-422.

Wessel, R. A., Blockmans, S. (eds), Between Autonomy and Dependence. The EU Legal Order Under The Influence of International Organisations (T.M.C. Asser Press/Springer 2013).

Wessel, R. A., Close Encounters of the Third Kind. The Interface between the EU and International Law after the Treaty of Lisbon (SIEPS 2013:8), Stockholm, Swedish Institute for European Policy Studies, December 2013.

de Witte, B., 'European Union Law: How Autonomous is its Legal Order?' (2010) 31 Zeitschrift für öffentliches Recht 141-155.

Ziegler, K. S., 'Autonomy: From Myth to Reality - or Hubris on a Tightrope? EU Law, Human Rights and International Law' (2015) 15-25 University of Leicester School of Law Research Paper.

Ziegler, K. S., 'International law and EU law: between asymmetric constitutionalisation and fragmentation' in A Orakhelashvili (ed), Research Handbook on the Theory and History of International Law (Edward Elgar 2011) 268-327.

Ziegler, K. S., 'The Relationship between EU Law and International Law' (2013) 15-19 University of Leicester School of Law Research Paper. 